Accepted refereed manuscript of: Okeke-Ogbuafor N. Gray T \& Stead SM (2020) The controversial role of foreign fisheries consultants in

Sierra Leone's coastal waters. Marine Policy, 118 https://doi.org/10.1016/j.marpol.2018.12.018

(C) 2018, Elsevier. Licensed under the Creative Commons Attribution-NonCommercial-NoDerivatives 4.0 International http://

creativecommons.org/licenses/by-nc-nd/4.0/

\title{
The controversial role of foreign fisheries consultants in Sierra Leone's coastal waters
}

\begin{abstract}
The use of foreign fisheries consultants in developing countries is increasing, despite growing controversy about their value. On the one hand, they bring expertise and analytic skills, which can turn around ailing fisheries, but on the other hand, their prescriptions may be inappropriate, based on ignorance or misunderstanding of local circumstances. This study, based on results from 51 key informant interviews and 199 survey questionnaires , finds the contributions of foreign fisheries consultants in Sierra Leone of limited benefit.
\end{abstract}

Keywords: Artisanal fishing; industrial fishing; fisheries management; fisheries policy

\section{Introduction}

The past 40 years has seen a large expansion in the use of consultancies by governments and businesses across the world [1, 2]. In developing African countries, foreign consultants are often perceived as more expert than their local counterparts [3, 4] and as a result, foreign consultancy in Africa is 'a booming business' [5]. However, some researchers question the quality of the services offered by foreign consultants, claiming they do not understand the complexity of the problem they are contracted to advise on [6, 7]. Poor policy recommendations, project failures, deficient evaluations of the impact of projects, expenditure that is vastly over budget, and corruption are frequent allegations [1-3, 8-12]. In fisheries management in developing countries the use of foreign fisheries consultants is common [13-17]. However, despite the increasing demand for, and use of, foreign fisheries consultants (FFCs) in Africa [3, 18, 19] not many studies have been conducted to assess the efficacy of these consultants. This paper aims to help fill this gap by investigating fisheries consultancy work in industrial and artisanal fisheries in Sierra Leone's Tombo and Goderich coastal communities.

\section{Sierra Leone's fisheries}

The fisheries sector in Sierra Leone contributes over 10\% to the country's GDP [20]. During 2014, revenue generated from this sector was calculated at US\$34 million, which is double that generated in 2013 [21]. The fisheries sector provides employment for about $8 \%$ of the country's working population, and is the main source of animal protein for local communities [22, 23]. However, during the eleven years (1991-2002) of civil war, most sectors of the country's economy, including fisheries, witnessed serious setbacks [24]. The war wasted over four decades of efforts previously invested in developing Sierra Leone's fisheries, because during it there was little or no enforcement of legislation, and very valuable fisheries data were destroyed [25]. Moreover, the civil war caused migration into coastal fishing communities, which increased the number of fishers [26]. Because of the lack of monitoring and surveillance, fishers used illegal nets such as mosquito nets and other types of small-mesh nets as well as monofilament nets and dynamite [27]. After the war ended, the government's financial position was very weak, and it could not afford to enforce fisheries regulations. Neiland et al., [21] say the Ebola epidemic in 2014-2016 may have increased the number of illegal vessels in Sierra Leone waters since during the outbreak, the Ministry of Fisheries and Marine Resources and other offices responsible for monitoring and surveillance were in lock-down [see also 28].

The fisheries sector in Sierra Leone currently faces severe problems of over-fishing. About $10 \%$ of the country's six million people depend heavily on small-scale artisanal fishing for food [25], and this puts heavy pressure on the stocks. This pressure is compounded by large-scale industrial fishing conducted mainly by foreign vessels, some of which fish legally with licenses issued by the government, but many fish without licences and constitute illegal, unreported and unregulated (IUU) fishing. Although the total amount of fish landings in Sierra Leone is uncertain because there are few officials who collect data at landing sites [24], it is suggested that out of the estimated total annual legal production of about 150,000 tonnes, the artisanal sector produces 142,000 tonnes and the legal industrial sector (mostly foreign vessels [29]) produces 8,000 tonnes, while an amount of 
fish estimated at a value of US\$30 million annually is taken by IUU vessels. The problem of IUU fishing is acute in Sierra Leone and is blamed by observers for the alarming decline in both the number and size of fish in the country's inshore waters. IUU is facilitated by Sierra Leone's very weak monitoring, control and surveillance system [28, 15, 30]. This illegal fishing not only reduces fish stocks, but removes fish from local markets $[15,30]$. Consequently, despite its rich marine resources, Sierra Leone is one of the world's poorest countries [31-35]

\section{FFCs in Sierra Leone}

In Sierra Leone, the Food and Agriculture Organization claims it has achieved much by working in partnership with key ministries to deliver its priority objective for costal fisheries - food security [13, 16]. The World Bank has worked with the New Partnership for Africa's Development supporting the Sierra Leone West African Regional Fisheries Project, which started in August 2010 with the aim of improving the country's capacity to manage its fisheries [36]. The work of foreign fisheries consultants in Sierra Leone has concentrated on two fishery sectors: industrial and artisanal. Foreign fisheries consultants from the World Bank worked with the Ministry of Fisheries and Marine Resources to develop a Joint Monitoring Centre in 2012 to track illegal fishing in the industrial sector $[15,28,37]$. This initiative was successful in reducing the number of illegal trawlers by over 50\%. On Sierra Leone's artisanal fisheries, foreign fisheries consultants and their governmental partner, the Ministry of Fisheries and Marine Resources claimed the West African Regional Fisheries Project was successful [36, 38] in achieving a review of the 1994 Fisheries Management and Development Act and the 1995 Fisheries Regulations [39], and the creation of Community Management Associations for the co-management of fisheries. According to foreign fisheries consultants, the success of the Community Management Associations in improving SL's artisanal fisheries was a result of the technical support they gave them [36, 38], and the New Partnership for Africa's Development claims to be one of Africa's 'leading think tanks' and fisheries experts, proposing innovative ideas that have improved the lives of fishing communities in Sierra Leone [40].

To evaluate these and other claims about the work of the numerous foreign fisheries consultants at work in Sierra Leone, this study investigates the perception of stakeholders, based on the results of 51 semi-structured key informant interviews and 199 survey questionnaires. The methods of obtaining and analysing data are explained and defended in a Supplementary Material file.

\section{Results}

\subsection{Foreign fisheries consultants' work with the industrial sector}

Many respondents were critical of the efforts made by foreign fisheries consultants to reduce IUU fishing in Sierra Leone waters. For instance, $40 \%$ and $58 \%$ of completed questionnaires returned from Tombo and Goderich, respectively, criticized the strategies used by foreign fisheries consultants. Most key informant interviewees thought the foreign fisheries consultants-recommended Joint Monitoring Centre did not do much to reduce IUU fishing in Sierra Leone, and it was closed down after two years of operation due to lack of funds, electricity shortages, storm damage, and unreliable internet connection [42]. Key informants blamed the failure of the Joint Monitoring Centre on the fact that foreign fisheries consultants did not undertake sufficient research to understand the character or trends of IUU fishing in Sierra Leone waters. For example, key informant-14, a scientist, pointed out that foreign fisheries consultants persuaded the Ministry of Fisheries and Marine Resources to require trawlers to install transponders, which verified their locations, but ignored the fact that there was no government resource to check that the transponders were not switched off or to monitor the data recorded by them. Also, foreign fisheries consultants did not acknowledge that unlicensed boats will not have transponders, and the Joint Monitoring Centre lacked the capacity to carry out physical monitoring ( key informant-8). 
Negative assessments of the work of foreign fisheries consultants with the artisanal fisheries included the charge by key informant-34, a fisherman from Goderich, that the ideas foreign fisheries consultants brought to the country's coastal fisheries were abstract, theoretical, and western - based on 'book knowledge' - not ideas customised for the particular circumstances of coastal fisheries in Sierra Leone, but merely designed to stop them fishing. Key informant-6, an official at the Ministry of Fisheries and Marine Resources, said recommendations from foreign fisheries consultants were not based on reliable research. Other respondents complained that the knowledge transfer model from foreign fisheries consultants was purely one-way - from foreign fisheries consultants to Ministry of Fisheries and Marine Resources and finally to fishers - not twoway, including valuable feedback from fishers. Key informant-6 said "it is imposition...we want foreign partners that will not impose their ideas on us. Rather we want partners that will sit with us and dialogue and work in our terms, and not in their terms, in the way that it will favour every Sierra Leonean". Key informant-

11815 said that foreign fisheries consultants often acted unilaterally in a top-down manner, bypassing the 119 Community Management Associations. He cited foreign fisheries consultants from the World Bank who repeatedly pushed their 'wealth creation' agenda despite the Ministry's opposition to it. Key informant-6 complained that foreign fisheries consultants often ignored the Ministry of Fisheries and Marine Resources: "World Bank will not listen to us [Ministry of Fisheries and Marine Fisheries], they do not consult us". A further charge was that foreign fisheries consultants frequently changed their minds in the advice they gave about artisanal fisheries. For example, key informant-6 described a World Bank-sponsored project which constantly altered shape as different consultants were brought in. Also, there were reported cases of corruption and mismanagement of the West African Regional Fisheries Project [28, 42].

Foreign fisheries consultants were also criticised for recommending the establishment of the Community Management Associations without ensuring they would be provided with the funding necessary for them to do their jobs adequately: "we [Community Management Association] are ready to work...we know our work, our only problem is money" ( key informant-9). Nor did foreign fisheries consultants check that Community Management Associations were adequately monitored in the way they performed their responsibilities. Officers of Community Management Associations were accused of turning a blind eye to illegal fishing activity. Key informant-10, an executive of the Community Management Association based in Tombo, asserted, "the Community Management Association is not prepared for this fight. Everything is very bad, all our executives are trying to make money. They are looking for money not following the law. Now because of their interest, they put money first and not good fishing". Indeed, managers of Community Management Associations were themselves accused of engaging in harmful or illegal fishing.

Finally, criticism was made about the so-called 'sensitization' programme recommended by foreign fisheries consultants to persuade artisanal fishers to stop using small mesh nets which caught immature fish, and monofilament nets which did not biodegrade after being lost but continued to 'ghost fish'. Whether such sensitization had any effect was doubtful. Key informant-36, a fisherman from Tombo, said "since 2015, we have been doing sensitization so that our people [fellow fishermen] can stop bad fishing. I do not know whether we are getting results". Key informant- 23, another local fisherman from Tombo, said that despite the sensitization campaign by the Ministry of Fisheries and Marine Resources against monofilament nets, he still used them "the marine are the people that say we should sensitize our people to stop using bad method...I use monofilament because it catch plenty big Bonga". In Tombo, results from the survey questionnaires showed that $67 \%$ of fishers used monofilament nets.

\section{Discussion}

There are four questions discussed in this section. The first is whether foreign fisheries consultants have improved Sierra Leone's artisanal fisheries, and the answer appears to be no. Foreign fisheries consultants could not sustain their Joint Monitoring Centre beyond 24 months, and there has been a steady increase in the amount of IUU fishing since its establishment in 2012 [43, 44]. Moreover, foreign fisheries consultants can be criticized 
for failing to change the mind-set of the artisanal sector, which includes the belief that fish come from God and this guarantees their continuous supply. This raises the second question, which is whether foreign fisheries consultants understood Sierra Leone's coastal fisheries. The literature is insistent about the need for foreign fisheries consultants to be fully aware of all the circumstances of the fisheries they purport to improve, and to be in synchronisation with the perceptions and values of their clients [45], but foreign fisheries consultants in Sierra Leone do not appear to have fulfilled these requirements. This may be because their communication skills were inadequate, which is the issue raised by the third question. Jacobson et al., [46] claim that maintaining healthy relationships between consultants and their clients is essential to ensure that projects are successful [see also 4]. In the case of Sierra Leone, foreign fisheries consultants seemed to lack communication skills in relation to both industrial fishermen and artisanal fishermen. In the industrial sector, according to key informant- 8 , a local consultant attached to foreign fisheries consultants said Sierra Leonean politicians sometimes interfered in communications between foreign fisheries consultants and the Ministry of Fisheries and Marine Resources, presenting counter-information to the Ministry and to industrial fishers ( key informants-1, 2, 4, 6, 7, 8, 16). In the artisanal sector, most foreign fisheries consultants followed a linear progression method of knowledge transfer from foreign fisheries consultants to the Ministry of Fisheries and Marine Resources, then to executives of Community Management Associations, and finally to fishermen at large, but during this process, important information about fishermen and from fishermen was often lost and therefore not available to improve the knowledge transfer process. The fourth question is whether the experience of foreign fisheries consultants in Tombo and Goderich differed. The results indicated that Goderich fishers were regarded as more responsible than Tombo fishers. For example, results from the survey questionnaire indicated that while $67 \%$ of Tombo fishers used monofilament nets, only $22 \%$ from Goderich did so. Yet Community Management Associations were no more popular in Goderich than in Tombo, which suggests that Community Management Associations (and therefore foreign fisheries consultants) are not responsible for the comparatively good behaviour of Goderich fishers. What appears to have had more influence on Goderich's fishers is the high quality of leadership displayed by the chairman of Capital River Warf - a local organisation that has nothing to do with Goderich's Community Management Association ( key informant-18).

\section{Conclusion}

In conclusion, this study found evidence that foreign fisheries consultants are deeply involved in Sierra Leone's artisanal and industrial fisheries, but stakeholders (local fishers, fisheries managers, and local researchers) are critical of their contributions, claiming that they do not really understand the coastal fisheries, lack communication skills; and base their interventions on outside perspectives. This study recommends that consultancy advice offered by foreign fisheries consultants in Sierra Leone should be based on a deeper understanding of the situation and views of artisanal fishers; on more rigorous research; and be subject to stricter post-project appraisal, as suggested in [6].

\section{Acknowledgements}

We are grateful to all participants in this research, including staff of the Ministry of Fisheries and Marine Resources, the leaders of the Sierra Leone Artisanal Fishers Union and Community Management Associations in Goderich and Tombo, and the fishers who completed survey questionnaires. Special thanks go to to Engr Kingsley Azubike Okonkwo of Total E\&P Nigeria for funding the fieldwork in Sierra Leone. We are also grateful to the Marine Policy anonymous reviewer and to Mr Christopher Azubike, Newcastle University, for their constructive feedback on earlier versions of this paper.

\section{References}

1 S. Applelbaum, A. Steed, 'The critical success factors in the client-consulting relationship', Journal of Management Development 24(1) (2005) pp.68-93 
2 S. Pellegrinelli,, 'Managing the interplay and tensions of consulting interventions: The consultantclient relationship as mediation and reconciliation,' Journal of Management Development 21 (5) (2002) pp.343-365

3 L, Ika, J Saint-Macary, 'Why do projects fail in Africa?', Journal of African Business, 15(3) (2014) pp. 151-155.

4 L. Martinez, A. Ferreira, A Can, 'Consultant- client relationship and knowledge transfer in smalland medium- sized enterprises change processes', Psychological Reports, 118 (2), (2016) pp. 608625.

5 S. Belew, 'Niche markets for consultants', (2017) https://www.thebalance.com/growing-consultantsniche-markets. 845810 [Online] (Accessed: 2/02/2018).

6 E. Penno, R. Gauld, ' The role, costs and value for money of external consultancies in the health sector: A study of New Zealand's District Health Boards', Health Policy 121 (4) (2017) pp. 458-467

7 K. Holgeid, M. Thompson, 'A reflection on why large public projects fail', (2013) https://www.jbs.cam.ac.uk/fileadmin/user_upload/programmes/emba/downloads/A_Reflection_on_Wh y_Large_Public_IT_Projects_Fail_-_Kjetil_Mark_Thompson_s_chapter.pdf [Online] (Accessed: $5 / 3 / 2018)$.

8 D. Wight, J. Ahikire, J. Kwesiga, 'Consultancy research as a barrier to strengthening social science research capacity in Uganda', Social Science \& Medicine 116, (2014) pp 32-40

9 J. Chelliah, D. Davis, 'What clients really want from management consultants: Evidence from Australia’, Journal of International Management Studies 6(11), (2011) pp.22-30

10 M. Ajmal, F. Nordstrom, P. Helo, 'Assessing the effectiveness of business consulting in operations development projects', International Journal of Productivity and Performance Management 58 (6) (2009) pp.523-541

11 N. Kakabadse, E. Louchart, A. Kakabadse, 'Consultant's role: A qualitative inquiry from the consultant's perspective', Journal of Management Development, 25(5), (2006) pp. 416-500

12 R. Bennett, C. Smith, 'The selection and control of management consultants by small business clients', International Small Business Journal, 22 (5), (2004) pp 435-462

13 FAO 'Sierra Leone and FAO building resilience and sustainable food and nutrition security', (2017) http://www.fao.org/3/a-au073e.pdf [Online] (Accessed: 17/2/2018).

14 L. Kassam, K. Lakoh, C. Longley, M. Phillips, S. Siriwardena, 'Sierra Leone fish value chain with special emphasis on Tonkolili District', (2017) pp. 1-52, http://pubs.iclarm.net/resource_centre/201733.pdf [Online] (Accessed: 5/02/2018).

15 R. Finch, 'The evil empire- how the Common Fisheries Policy is recolonising the Third World', (2016) pp. 2-60, http://www.efddgroup.eu/newsroom/latest-news/the-evil-empire-how-the-commonfisheries-policy-is-recolonising-the-third-world [Online] (Accessed: 21/2/2018).

16 FAO 'Voluntary Guidelines on the Responsible Governance of Tenure of Land, Fisheries and Forests in the Context of National Food Security', (2012) pp. 1-40, http://www.fao.org/docrep/016/i2801e/i2801e.pdf [Online] (Accessed: 5/2/2018). 
17 NEPAD (nd-a) 'African fisheries continue to grow', http://www.nepad.org/content/african-fisheriescontinues-grow [Online] (Accessed: 4/2/2018).

18 L. Ika, 'Project management for development in Africa: Why projects are failing and what can be done about it', Project Management Journal, 43(4), (2012) pp. 27-41.

19 R. Youker, 'The nature of international development projects', (2003) PMI Global Congress 2003. North America Baltimore.

20 L. Taylor-Pearce, 'Audit service Sierra Leone: Performance audit report on generation and collection of revenue in the fisheries sector', (2012) http://www.auditservice.gov.sl/report/assl-performanceaudit-report-2012-09-18-fisheries-revenue.pdf [Online] (Accessed: 5/02/2018).

21 A. Neiland, S. Cummingham, M. Arbuckle, A. Baio, T. Bostock, D. Coulibaly, N. Gitonga, R. Long, S. Sei, 'Assessing the potential contribution of fisheries to economic development - The case of postEbola Sierra Leone', Natural Resources, 7 (6) (2016).

22 E. Manns, 'Sierra Leone News: Fishing is a major contributor to Salone's economy', (2017) https://awoko.org/2017/06/19/sierra-leone-news-fishing-is-a-major-contributor-to-salones-economy/ [Online] (Accessed: 6/02/2018).

23 MFMR, 'Ministry of Fisheries and Marine Resources: Management and functional review - Update', (2012) pp. 1-56, http://psru.gov.sl/sites/default/files/sites/default/files/reports/MFR\%20Update\%202012\%20Fisheries \%20\%26\%20Marine\%20Resources.pdf [Online] (Accessed: 7/03/2018).

24 A. Thorpe, D. Whitmarsh, E. Ndomahina, A. Baio, M. Kemokai, T. Lebbie, 'Fisheries and failing states: The case of Sierra Leone', Marine Policy, 33(2), (2009) pp. 393-400.

25 K. Seto, D Belhabib, D. Copeland, M. Vakily, S. Sankoh, A. Baio, I.Turay, S. Harper, D, Zeller, K. Zylich, and D. Pauly (2015) 'Colonialism, conflicts and fish: A reconstruction of marine fisheries catches for Sierra Leone 1950-2010',www.searoundus.org/doc/publications/wp/2015/seto-et-al-sierraleone.pdf [online] (Accessed 6/03/2018)

26 P. Davis, 'Ebola in Sierra Leone: Economic impact and recovery', (2015) pp. 1-33, https://www.adamsmithinternational.com/documents/resource-uploads/Ebola_in_Sierra_Leone.pdf [Online] (Accessed: 21/02/2018).

27 A. Khan, S. Sei, The co-governance of fisheries in post- conflict Sierra Leone: Is the transition for better or for worse? In Jentoft, S., Chuenpagdee, R..(eds) Interactive Governance for Small-Scale Fisheries. Switzerland: Springer, Cham. (2015)

28 A. Doumbouya, O. Camara, J. Mamie, J. Intchama, A. Jarra, S. Ceesay, A. Gueye, D. Ndiaye, E. Beibou, A. Padilla, D. Belhabib, 'Assessing the effectiveness of monitoring control and surveillance of illegal fishing: The case of West Africa', Frontiers in Marine Science, 4. (2017) pp. 1-5

29 K. Seto, D. Belhabib, J. Mamie, D. Pauly, 'War, fish, and foreign fleets: The marine fisheries catches of Sierra Leone 1950-2015' Marine Policy 83 (2017) pp 153-163 
30 A. Thomas, 'Sierra Leone is losing over 100 million dollars from its fishing industry', (2016) http://www.thesierraleonetelegraph.com/sierra-leone-is-losing-over-one-hundred-million-dollars-fromits-fishing-industry/ [Online] (Accessed: 4/02/2018).

31 O. Gooding, 'Sierra Leone News: 2016 HDI: Sierra Leone ranked 179 out of 185', (2017) https://awoko.org/2017/03/23/sierra-Leone-news-2016-hdi-sierra-Leone-ranked-179-out-of-185 [Online] (Accessed: 2/02/2018).

32 R. Coyle, H. Harrison, 'Emergency care capacity in Freetown, Sierra Leone: A service evaluation', BMC Emergency Medicine, 15 (2), (2015) pp. 1-9.

33 A. Faroh, 'Economic growth and poverty reduction in Sierra Leone', International Journal of Economics, Commerce and Management, 111 (2), (2015) pp. 1-17.

34 K. Kliesner, 'Brutal poverty in Sierra Leone', (2014) https://borgenproject.org/widespread-povertysierra-leone/ [Online] (Accessed: 21/1/2018).

35 R. Glennerster, E. Miguel, A. Rothenberg, A. 'Collective action in diverse Sierra Leone communities', (2010) pp. 1-55, http://www.nber.org/papers/w16196.pdf [Online] (Accessed: 5/02/2018).

36 MFMR 'Annual Progress Report of WARFP-sl, Freetown, Sierra Leone MFMR' (2014).

37 D. Agnew, J. Pearce, P. Ganapathiraju, T. Peatman, R. Watson, J. Beddington, T. Pitcher, 'Estimating the worldwide extent of illegal fishing', PLoS ONE, 4 (2) (2009).

38 S. Akester, 'How improving fisheries governance in West Africa improves fishermen's livelihoods', (2018) http://blogs.worldbank.org/voices/how-improving-fisher [Online] (Accessed: 6/03/2018)

39 FAO, 'Improving the artisanal fisheries management of Liberia and Sierra Leone', (2010) http://www.fao.org/fishery/docs/DOCUMENTleaf-nansen [Online] (Accessed: 5/03/2018).

40 NEPAD (nd-b) 'NEPAD Agency Fisheries and Aquaculture Programme, Johannesburg, NEPAD

41 Kamara, 'Sierra Leone News: Increase in illegal fishing - World Bank frowns at JMC closure', (2016) https://awoko.org/2016/02/11/Sierra. Leone-news-increase [Online] (Accessed: 4/3/2018).

42 World Bank, 'First Phase of APL-A in support of the West Africa Regional Fisheries Program (WARFP APL A1)', (2011) pp. 1-26, http://documents.worldbank.org/curated/en/534561467990085196/pdf/618150PJPROP120e0only0900 BOX361483B.pdf [Online] (Accessed: 4/03/2018).

43 J. Margai, ' 60\% illegal fishing in Salone waters' (2016) http://slconcordtimes.com/60-illegal-fishingin-salone-waters (Accessed 13 July 2018)

44 O. Gooding, ' Illegal fishing threatens fisheries-Marine Report', (2017) http://www.iuuwatch.eu/2017/06/sierra-leone-news-illegal-fishing-threatens-fisheries-marine-report [Online] (Accessed: 2/02/2018).

45 P. Christensen and K.Klyver 'Management consultancy in small firms: How does interaction work? Journal of Small Business and Enterprise Development 13(3), (2006) pp. 299-313 
46 N. Jacobson, D. Butterill, P. Goering, 'Consulting as a strategy for knowledge transfer', Multidisciplinary Journal of Population Health and Health Policy, 83 (2), (2005) pp. 1-6. 